tion 1

\title{
Salton Sea Scientific Drilling Plan and Well Designs
}

\author{
Submitted to \\ Bechtel National Inc.
}

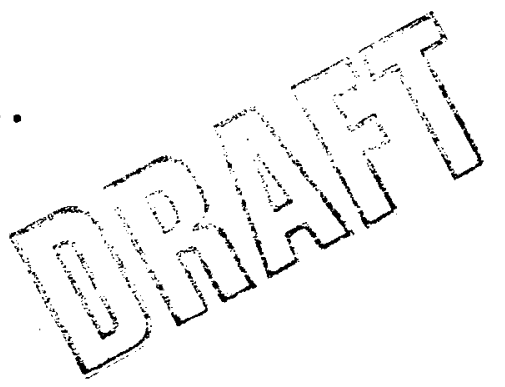

by

Berkeley Group Inc.

February 1985 


\section{DISCLAIMER}

This report was prepared as an account of work sponsored by an agency of the United States Government. Neither the United States Government nor any agency Thereof, nor any of their employees, makes any warranty, express or implied, or assumes any legal liability or responsibility for the accuracy, completeness, or usefulness of any information, apparatus, product, or process disclosed, or represents that its use would not infringe privately owned rights. Reference herein to any specific commercial product, process, or service by trade name, trademark, manufacturer, or otherwise does not necessarily constitute or imply its endorsement, recommendation, or favoring by the United States Government or any agency thereof. The views and opinions of authors expressed herein do not necessarily state or reflect those of the United States Government or any agency thereof. 


\section{DISCLAIMER}

Portions of this document may be illegible in electronic image products. Images are produced from the best available original document. 

Preface

The following report has been submitted as a draft in partially completed form to Bechtel National Inc. at their request.

The initial BGI contract with Bechtel spectesthat BGI would provide

"draft input to each of the activities. Bechtel will prepare final specifications."

The preparation of this report is outside the scope of our original contract under which there were no reporting requirements.

Due to schedule demands we have provided only the sections that the Bechtel technical manager has requested. The remainder of the report is being prepared and complete reports will be delivered at a later date.

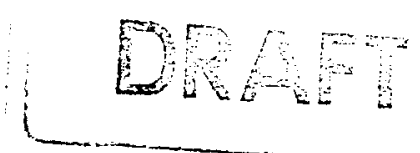


1. Introduction and Summary

- Project Scope

- Well locations for production/injection

- Resource properties

- Design criteria

- Drilling program

- Contingencies

2. Fermation Characteristics

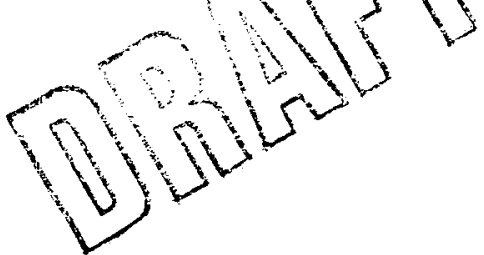

- Rock types (fracture, sedimentary)

- Static condition (estimated to depth)

- Salinity

- Corrosion potential

\section{Completion Design}

3.1 Expected Reservoir/Wellbore Conditions

- Injection

- Production

- Drilling

- Cementing

- Circulating

3.2 Wellhead Design (material properties)

- Pressure

- Temperature

- Safety Factors

\subsection{Casing Design (material properties)}

- Design factors

- Production Iiner

- Production-interval liner 


\subsection{Cementing Program}

- Design factors

- Review of cementing each string

\subsection{Miscellaneous}

- Rig test piping for testing

- Casing and drill pipe inspection

- Logging activities (electrical)

\section{Driling Program}

- Borehole sizes

- Drililing rates

- Core depths

- Deviation and control, whipstocking

- Pull-out of hole rates

- Circulation rates

- Rig type (pump capacity, load, derrick height)

\subsection{Drilling Assemblies}

- General discussion of hydraulics and geothermal

- bits (weight on bit)

- Type of bits (nozzle diameters)

- Reamers

- Stabilizers

- Heavyweight pipe

- Collars

- Shock sub

\subsection{Mud Program}

- Mud properties (FI, VIS, additives and description)

- Volumes used

- Volumes lost per day

- Requirements for mixing new mud

- Solids control

- Water treatment

- Mud cooling equipment

- Geologic logging 
5. Drilling Procedures (daily activities)

- BOP equipment

- Bits needed

- Core bits and barrels needed

- Temperature surveys

- Time versus depth

a) drilling

b) coring

c) circulation

d) casing

e) cementing

f) pullout of hole

g) run-in hole

- Drilling operation

- Cementing operation

6. Flow Testing with Rig on Hole

- Heat-up

- Cool down

- Kickoff with $\mathrm{N}_{2}$

7. Appendices

- Design criteria

- Daily drilling plan

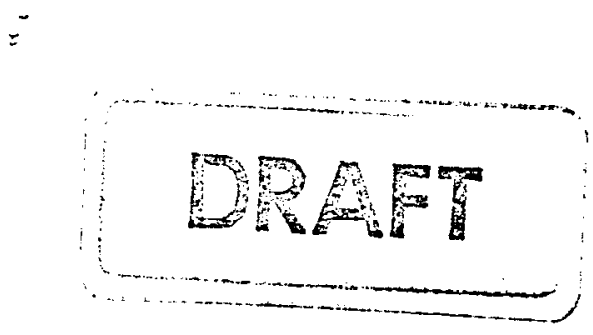




\section{Introduction and Summary}

Project Scope The purposes and goals of the Scientific Deep Drilling Program have been outlined in previous documents. The purpose of this report is to provide supporting documentation for the engineering recommendations and detal specifications associated with the drilling program.

The drilling plan developed for Bectitel and described below has been revised several times due to changes in the project scope and project guidelines. Some of these changes were made due to the unforseen cost implications associated with certain drilling operations and specifications. Some of the revisions were in response to DOE requests to Bechtel. The revisions have required the rewriting of some of the draft input for resubmission to Bechtel.

The current drilling project scope includes the following guidelines.

- Drill to a depth at which the temperature is approximately $572 \mathrm{~F}$ (300C).

- Drill approximately 6000 feet deeper than the $572 \mathrm{~F}$ depth (estimated 10,000 feet).

- Complete the well to allow production for up to 30 days.

- Make the well available, after drilling, for scientific experimentation.

- Attempt to retrieve cores from about $15 \%$ of the total depth.

- Attempt to retrieve four of those cores from depth

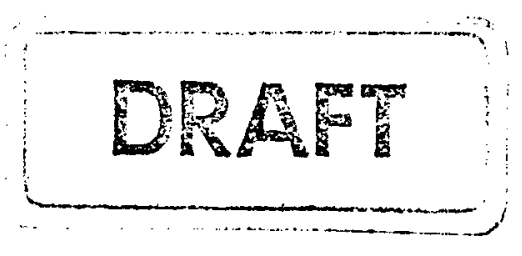


between 500 and 3000 feet.

- Attempt geophysical borehole logs prior to setting intermediate and production casing strings.

- Provide casing termination at the surface that will allow a hang-down liner (do not inolude the hang-down liner in the draft specifications).

- No flow tests will be scheduled pritor to reaching total depth.

- No rig standby time is to be-śpecified in the driliing plan or draft inptit to specifications.

- The well should be designed to last up to one year without failure due to corrosion or borehole instability.

- An injection well will be drilled to about 4000 feet.

- The injection well must have at least a one year lifetime.

- The injection well must be capable of accepting the maximum potential flow from the production well.

- Geophysical wellbore logs will be attempted in the injection well prior to setting casing.

- No attempts at retrieving core will be made while drilling the injection well.

- Well testing and brine handling specifications and plans are outside the scope of this report.

The guidelines listed above have evolved during the numerous design iterations that have already been made and evaluated. Many of the guidelines have been defined for cost-related reasons. For example, the scientific experiments and the well testing is assumed to take place after the rig has been released 


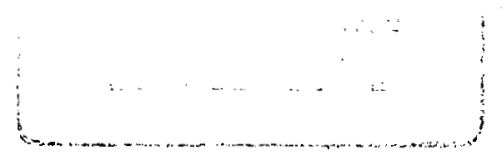

because of the additional cost of up to 30 days of standby charges. Another example of a cost-related guideline is the we have planned for "attempts at core retrieval". In order to keep the number of drilling days at a minimum we assume that only one attempt to retrieve core will be made each i20 feet from 3000 feet to bottomole depth. The drilling piplpecifies the use of a 30 foot corebarrel, and when this corebarrel is run every 120 feet it has the potential to retrieve about 1500 feet of the total drilled depth of 10,000 feet if each attempt is $100 \%$ successful. Therefore, since core retrieval in the fractured portions of the well will almost certainly be much less than $100 \%$, the total "retrieved" core from the well may be much less than 15\% of the total drilied depth.

Some of the design iterations included coring at bit change, continuous, coring, and wireline coring. These possibilities (and others) were all rejected as being either technically infeasible or too costly. If coring is done on bit change there is not sufficient "potential core footage" to meet the $15 \%$ guideline.

Flow tests with the rig on the hole were rejected as too costly and mechanically difficult except for a one to two day pit test after completion to clean out the well. The requirement of 30 days of rig standby time after drilling is not included. Coring the injection well was considered unnecessary 
and too costly. All of these guidelines play a part in the well design and drilling plan and were requested or authorized by Bechtel.

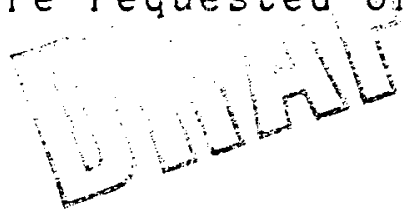

Locations of the Wells Figure 1.1 shows the approximate locations of the production well $14-2$ and the injection well 13-9. The production well location has been defined by Bechtel to be 400 feet west and 400 feet north of a permanent marker at the intersection of Davis and McDonald Roads. The outline of the Salton Sea shown on the map is no longer correct, and should not be used for reference.

The locations of the nearby wells should be noted as they are referred to in the section below covering the resource properties.

Resource Properties The general guidelines for the project, as outlined above, together with the resource properties result in numerous restrictions and requirements on the well design. For this reason we will review the resource properties before summarizing the design criteria.

The Imperial Valley is a sediment-filled trough formed by relative tectonic movement of the Pacific and continental plates. The high temperature of the resource is related to thermal convection of hot fluids from the deepest parts of the 


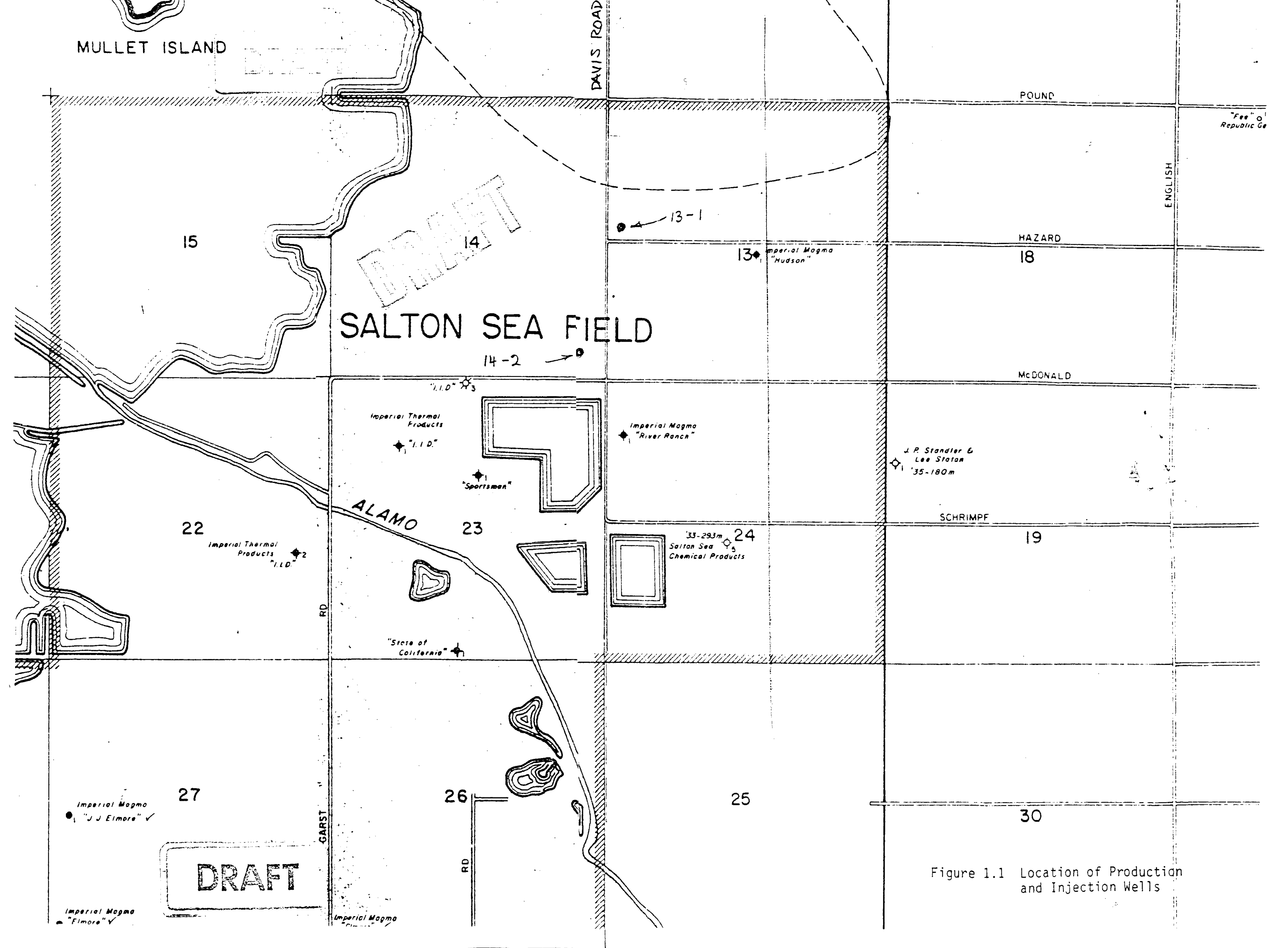


reservoirs to the shallower depths. "The "temperature in the nearby Elmore $\$ 1$ well has been used as the guideline for the highest probable resource temperature profile and is discussed below in section 2. When the Elmore \#1 temperature profile is extrapolated to about 10,000 feet the temperature is predicted to be in excess of $700 \mathrm{~F}(370 \mathrm{C})$.

The resource brine is composed primarily of a chloride solution. There are also metals, sulfur, gases, and silica dissolved in the brine. The brine is highly corrosive at all temperatures. Experience in the Imperial Valley shows that well-life can be as short as 3 months and as long as a few years, depending on the resource location, brine characteristics and completion design.

Well Design As indicated above, the combination of project guidelines and resource properties results in some necessary well design parameters. These design parameters have been reviewed by the DOE Industry Advisory Panel. With the exception of some minor recommendations our initial well design was endorsed. Some of the design parameters for the production well are:

- Intermediate casing to about 3000 feet.

- Production casing to about 6000 feet.

- Optional production liner.

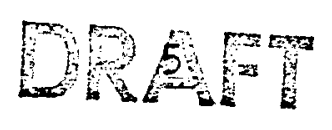


- Wellhead to meet ANSI 1500 lb service rating.

- Production casing with maximum yield for strength.

- Production casing with minimum yield to prevent hydrogen sulfide, $\mathrm{CO} 2$ and chloride induced failure.

Similar injection well parameters are:

- Intermediate casing to about 2000 feet.

- Injection/production casing to about 3000 feet.

- Injection liner $2800-4000$ feet.

- Wellhead to meet ANSI 900 lb service rating.

Contingencies some of the project guidelines are fundamental in scope. The absolute necessity of some guidelines could result in increased cost if our assumptions about the resource are not correct. For example, if the temperature is not $575 F$ or greater at 4000 feet, must we drill deeper than 10,000 feet? Since the time needed for drilling and coring below 10,000 feet is large, additional footage below 10,000 feet will be very costly.

Conversely, if the temperature is extremely high at depths shallower than 10,000 feet, must we continue to drill? If so the danger of exceeding the wellhead rating during flow tests is an emminent danger.

There are other contingencies that can have severe impact on cost. The most likely one is the possibility of getting stuck 
during coring or ariliing. Even without coring there is a relatively high incidence of stuck drill pipe in the Imperial Valley. This phenomenon is especially prevalent during loss of circulation. This problem sometimes requires fishing or sidetracking to drill around the stuck equipment. The fishing operation to remove stuck driling assemblies or sidetracking can be time consuming, costly problems.

Another contingency to be considered during driling of the potential production zone is loss of circulation. To drill the production zone for maximum flow requires minimizing the use of lost circulation material to prevent wellbore damage (permanent reservoir flow impairment). But to drill with a minimum risk of getting stuck requires continuous circulation and placement of LOC material. These incompatible requirements can lead to either a nan-productive well, or costly drilling problems.

The most difficult contingency to anticipate may be associated with coring. Under even the best conditions there is no guarantee of recovering complete cores. In the deeper parts of this well, below 4000 feet, we expect the rock to be brittle and fractured. This makes the likelihood of recovering large core percentages very small. The core recovery could be as small as $20 \%$, or less, of the core barrel length (less than 6 feet per attempt). This is highly likely and has not been addressed in this drilling program. Since the total drilling 
and coring time is currently about twice as long as the straight drilling time, additional attempts at core retrieval (especially from the deeper depths) would increase the cost of drilling significantly.

1

$=$

$+2$ 


\section{Eormation Characteristics}

There is a large amount of data available covering the formation properties at the salton sea. The majority of the data has been made available through the DOE Salton Sea Projects. The latter were primarilly under the direction of the Lawrence Livermore Laboratory and the field developers. The data obtained and published by LLL included temperature profiles, analyses of cuttings, and well test results. Most of the data is available from depths less than 5000 feet. However, well Elmore 1 was drilled to 7000 feet and the River Ranch \#1 well reached 8000 feet.

Most of the available well data is for shallow wells, but when the static temperature for the closest wells to $14-2$ and 13-1 are plotted, along with the Elmore \#1 data, they all extrapolaté to about 700 to $715 \mathrm{~F}$ at 10,000 feet. Figure 2.1 shows the comparison.

\subsection{Rock Types}

The sediments in the Salton Trough consist of recent sands, silts, and clays at shallow depths, and the deeper rocks are composed of similar, older sediments that have been metamorphosed due to high temperature and pressure at depth. The metamorphic mineral assemblages include common calcitic and silicic phases that are found in other geothermal resources 
Figure 2.1 Static Temperature Profiles

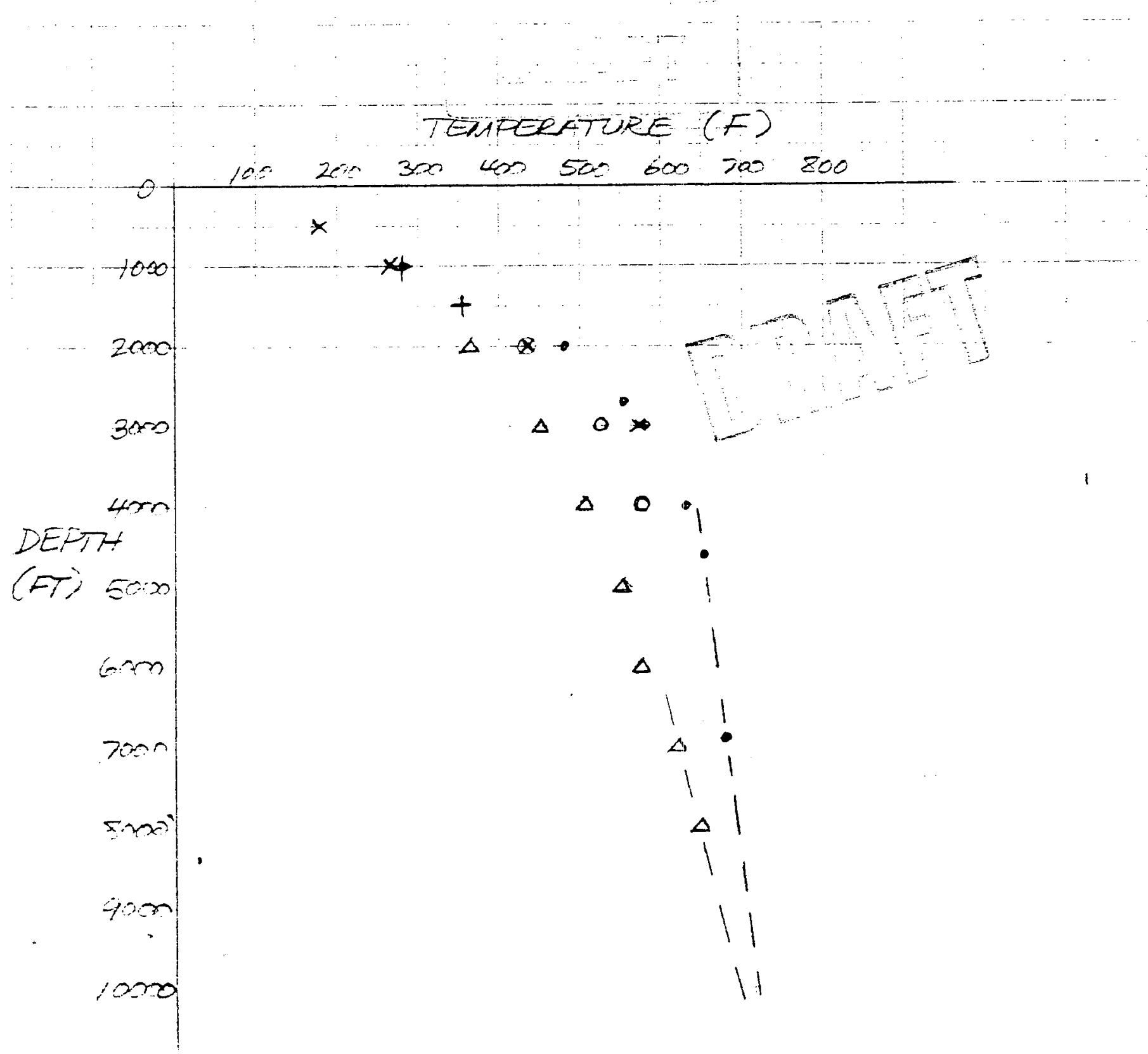

- elmore \#1

$x$ IID \#1

O SPORTSMAN \#I

+ IID $\# 3$

$\triangle$ RIVER RANCH 1 
around the world. The metamorphosed-rocks are found in inhomogeneous assemblages common to deltaic sediments. The metamorphosed sediments are relatively impermeable, brittle, and have low porosity. The active seismicity in the Salton Trough results in almost continuous epochs of fracturing cementation and refracturing. The pores and fractures are saturated with a saline brine.

\subsection{Static Conditions}

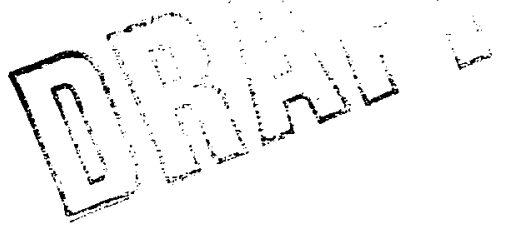

The assumed geothermal profile and hydrostatic profile used in the design are shown in Figure 2.2. The temperature profile is based on measurements made in Elmore 1 (Palmer 1975) which is located approximately 2 miles southwest of the proposed site for the Salton Sea Deep Well (SSDW). The Elmore \#1 profile was chosen as the design basis because it exhibits high shallow temperațures and as such represents a "worst case" condition for the well design.

The maximum temperature measured in Elmore \#1 was $680 \mathrm{~F}$ at 6900 feet. The design bottomhole temperature for the SSDW was estimated by extrapolating the temperature gradient in the bottom 2000 feet of the Elmore \#1 to the anticipated 10,000 foot completion depth. The bottom-hole temperature on this basis is $715 \mathrm{~F}$.

Inspection of chemistry data from the existing wells in the 
Figure 2.2

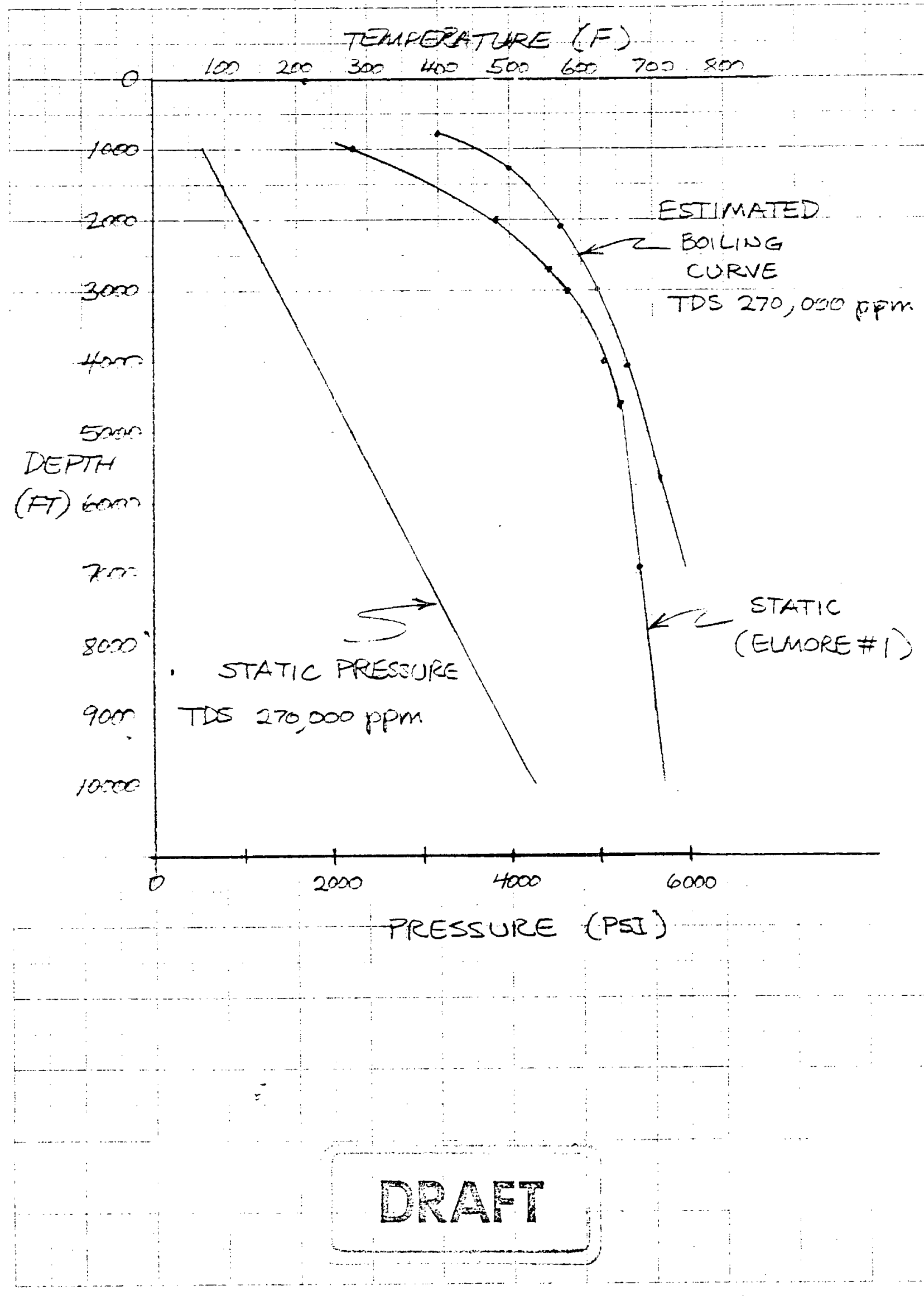




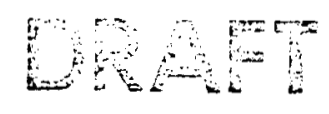

area suggests the salinity of the reservoir fluid is approximately $270,000 \mathrm{ppm}$ (Palmer 1975). The measured pressures in the existing wells indicate the formation is approximately hydrostatic from the surface.

The salinity and temperature profile alog with brine density data presented by Dittman were used to calculate the hydrostatic profile. The resulting hydrostatic pressure at 10,000 feet is 4230 psia.

Fluid properties were determined using data reported by Has (1971) for steam-brine mixtures. The saturation pressure for 27 percent salinity brine at $715 \mathrm{~F}$ is $2619 \mathrm{psia.} \mathrm{No}$ reliable data covid be found in the literature on noncondensable gas content. The effect of gas was assumed to be negligible in estimating the wellbore flowing conditions. However, gas was considered in calculating the design wellhead conditions. 


\subsection{Completion Design}

\subsection{Casing Program}

The casing program is shown in Figure 3.1 . The industry advisory panel recommended that the 30 inch conductor casing should be set to 60 feet to ensure the unconsolidated surface sands are adequately stabilized. The 20 inch surface casing will be set to a maximum 700 feet; however, a shallower setting is advisable if a sudden increase in mud return temperature is noted before the 700 foot depth is reached.

It is important to ensure an acceptable surface casing is in place while the $171 / 2$ inch diameter hole is drilled to 3000 feet. Formation temperatures could exceed $550 \mathrm{~F}$ in the lower part of this interval and productive zones may be encountered anywhere below 2000 feet. There is also the possibility that a shallow $\mathrm{CO}_{2}^{\prime}$ zone may be encountered in the near surface. The 20 inch cașing should be as deep as possible to ensure well kicks can be safely controlled.

In view of the high temperatures that are anticipated and the largely unknown formation and fluid conditions at depth we have opted for a final completion that includes an intermediate string of $133 / 8$ inch casing from the surface to 3000 feet and a $95 / 8$ inch production string from the surface to 6000 feet. This program ensures the length of uncased hole is kept to a minimum at any particular point in the program which greatly

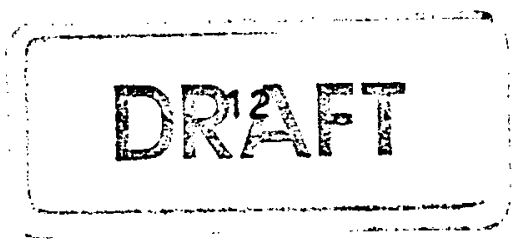


reduces the risks of hole instability problems developing.

The Elmore 19 temperature profile exhibits a gradual change from a conductive to convective gradient in the vicinity of 2000 feet to 4000 feet. This may represent the transition from the near surface formation and aquifers, to the geothermal reservoir. The casing depth of 3000 feet wasthosen to ensure the near surface aquifers are adequately protected from contamination by geothermal fluids. Moreover, the Elmore \#1 profile closely approaches the boiling point with depth curve in the region 3000 feet to 5000 feet as shown on Figure 2.2 . Spontaneous boiling and discharge could occur if wellbore temperatures are allowed to approach the formation temperature. Cementing the $133 / 8$ inch casing to 3000 feet will allow any well control problems that may occur to be safely dealt with.

Two major factors influenced the selection of 6000 feet for the $95 / 8$ inch casing depth.

1) The extensive coring operations planned for this well will require many round trips of the drilling assemblies. The associated interruptions in mud circulation and the regular running of pipe in and out of the hole may cause deterioration of the wall and promote severe sloughing, collapse or swelling problems. Minimizing the interval of open hole subject to Ënese conditions at any one time will

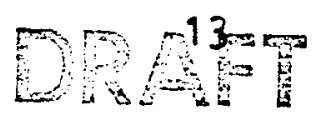


lessen the risk of severe hole problems occuring.

2) The projected bottom-hole temperature is $715 \mathrm{~F}$ and the corresponding saturation temperature 1 s 2699 psia. If the well produces from bottom-hole wh no drawdown then the wellbore fluid will begin fo flash when the pressure drops to 2619 psiallabove this point the fluid in the wellbore wh be at a higher pressure than the formation fluid and wellbore fluids could escape into the surrounding formation. This condition will occur above 6000 feet for the conditions projected for the SSDW. Casing to 6000 feet provides assurance that wellbore fluids will be contained within the well up to the surface. The 9 $5 / 8$ inch casing will be run and cemented to the surface to provide double string protection in the near surface portion of the well.

A 7 inch slotted liner is shown on the Figure. It is recommended that the liner be available on-site but run only if problems are encountered in maintaining the hole open during drilling and its stability over time is of concern.

\subsection{Welihead Design}

Two criteria were employed in determining the design wellhead conditión.

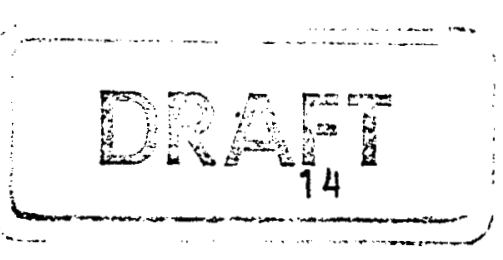


1) A steam column in the wellbore at the reservoir temperature (i.e. 715F).

2) A gas (50:50, H2S:CO2) column in the wellbore to the bottom of the cemented casing (6000 feet) at an assumed average temperature of $500 \mathrm{~F}$

The first criterion results in a maximum design wellhead pressure of 2200 psi and the second criterion results in a design wellhead pressure of 2250 psia. Based on these design conditions we recommend the critical wellhead components meet ANSI 1500 Ib service ratings. This would include as a minimum, the casing head flange, expansion spool, 3 inch wing valves (double valving), and double 10 inch master valves.

\subsection{Casing Design}

The three main conditions that the casing will be subjected to are: 1)'emplacement operations, 2) well discharging and 3) injecting (or circulating) cold fluids. The relevant loading and stress conditions include:

1) Collapse - (Due to external pressure) The design case is normally asssumed to occur when casing is being run empty into a mud filled hole. The worst case service condition occurs when the wellbore is hot and empty such as might occur when stimulating the well by pumping nitrogen through continuous tubing.

2) Iension - Tension stresses occur due to string weight,

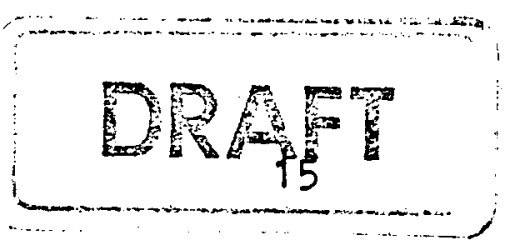


internal pressure and cooling-of the wellbore below the neutral (zero thermal stress) temperature.

3) Compression - Compression stresses occur when the wellbore is heated above the neutral temperature.

4) Burst - Stresses due to internal pressure.

In most cases the casing will experience a combined stress condition. For this reason a biaxial stress analysis was used in determining casing stresses and the maximum energy distortion theory was employed as the failure criterion.

Temperature changes in the well may be as high as 500F. For example, the temperature increase in the near surface between shut-in and flowing or the temperature decrease at 6000 feet between shut-in and injecting or circulating cold fluids could both approaich 500F. In this case, large thermal stresses will be produced by these large temperature changes and are the determining factor in the casing design. It is of interest to note that the thermal stress is a function of temperature, elastic modulus and the expansion coefficient only. Therefore, failure depends on material strength alone rather than a combination of strength and casing dimensions (e.g. wall thickness).

The thermal stress developed at a given well condition is a function of the čement bonding temperature since this will be 
the zero stress reference temperature of the casing. The cement bonding temperature is difficult, if not impossible to predict. For the purposes of this design we assumed the cement bonding temperature in the near surface would be $200 \mathrm{~F}$ and could be as low as $300 \mathrm{~F}$ or as high as $500 \mathrm{~F}$ at 6000 feet.

Another important factor that is particularly relevant to geothermal wells is creep. At high temperetures steel under stress will undergo significant creep. Creep will relax the stresses in the casing with time. It is virtually impossible to predict what the stress condition may be at a particular time and more importantly, what it is likely to be when the well condition is abruptly changed, such as when the well is discharged.

There is evidence that corrosion may be severe in this environment; however, the actual severity of the problem in terms of casing serviceability is unknown. For this reason the thickest wall casings that would permit the use of standard 12 $1 / 4$ inch and $81 / 2$ inch bits without special preparation were arbitrarily selected for the $133 / 8$ inch and $95 / 8$ inch strings. This approach provides a combination of maximum strength and maximum corrosion protection.

The casing material was selected on the basis of the stress calculations under the service conditions outlined in Table 3.1 . Only API grade cärbon steel casing materials were considered. 
Table 3-1

Summary of Design of $95 / 8^{\prime \prime}$

C95, 47\#, Buttress Casing String

\begin{tabular}{|c|c|c|c|c|}
\hline $\begin{array}{r}\text { Depth } \\
(\mathrm{ft})\end{array}$ & $\begin{array}{l}\text { Assumed Cement } \\
\text { Bonding Temp. }\end{array}$ & $\begin{array}{l}\text { Operation or } \\
\text { Service Condition }\end{array}$ & $\begin{array}{l}\text { oading } \\
\text { r Stress }\end{array}$ & $\begin{array}{l}\text { Design } \\
\text { Factor }\end{array}$ \\
\hline 6000 & - & $\begin{array}{l}\text { Running empty into } \\
9.5 \mathrm{lb} / \mathrm{gal} \text { mud }\end{array}$ & collapse & 1.52 \\
\hline 6000 & $300 F$ & Flowing at $700 \mathrm{~F}$ & compression & 0.96 \\
\hline 6000 & $300 F$ & $\begin{array}{l}\text { Injecting at } 1500 \text { psi } \\
\text { WHP, } 100 \mathrm{~F} \text { fluid }\end{array}$ & biaxial ${ }^{1}$ & 1.85 \\
\hline 6000 & $500 \mathrm{~F}$ & $\begin{array}{l}\text { Injecting at } 1500 \text { psi } \\
\text { WHP, 100F fluid }\end{array}$ & biaxial ${ }^{l}$ & 1.06 \\
\hline 6000 & $500 \mathrm{~F}$ & Wellbore hot but empty & collapse & 1.54 \\
\hline 6000 & $500 \mathrm{~F}$ & Flowing at $700 \mathrm{~F}$ & compression & 1.96 \\
\hline surface & $200 \mathrm{~F}$ & Running & weight & 4 \\
\hline surface & $200 \mathrm{~F}$ & $\begin{array}{l}\text { Injecting at } 1500 \text { psi } \\
\text { WHP, } 100 \mathrm{~F} \text { fluid }\end{array}$ & biaxial ${ }^{l}$ & 3.5 \\
\hline surface & $200 \mathrm{~F}$ & Flowing with $650 \mathrm{~F}$ WHT & biaxial ${ }^{2}$ & 1.16 \\
\hline 6000 & ' $\quad-$ & $\begin{array}{l}\text { Injection after creep } \\
\text { relaxation }\end{array}$ & biaxial ${ }^{1}$ & 0.87 \\
\hline surface & - & $\begin{array}{l}\text { Flowing after creep } \\
\text { relaxation }\end{array}$ & biaxial ${ }^{2}$ & 0.66 \\
\hline
\end{tabular}

1) Internal pressure with axial tension

2) Internal pressure with axial compression

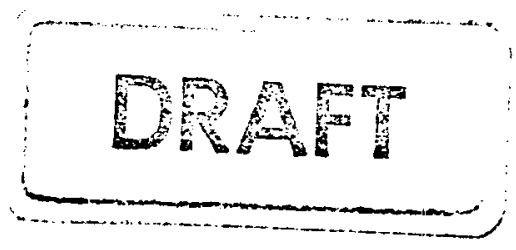


Of these the highest strength considered was c95 (95,000 psi minimum yield) since there is evidence that very high strength steels are subject to stress cracking in high chloride and hydrogen sulfide environments (Greenip 1978).

Buttress thread joints were selected for the $95 / 8$ inch and $133 / 8$ inch strings. Buttress thread joints offer strengths similar to the pipe body itself and are widely usedin geothermal applications.

The inner casing strings could reach temperatures of the order of $700 \mathrm{~F}$ when the well is flowing. Published data on the properties of casing at elevated temperatures was reviewed and indicated that yield strength at $700 \mathrm{~F}$ is approximately 80 percent of the cold yield for a wide range of casing steels (see Snyder 1980, Nicholson 1984).

Based on the above described approach the two selected inner strings, are as follows:

\section{5/8 inch casing}

Specification: API grade C95, 47 \#/ft, Buttress |

Wall Thickness $=0.472^{n}$

Joint Area (minimum) $=10.47 \mathrm{sq}$. in.

Cold yield $=95,000 \mathrm{psi}$

Hot yield $=76,000 \mathrm{psi}$

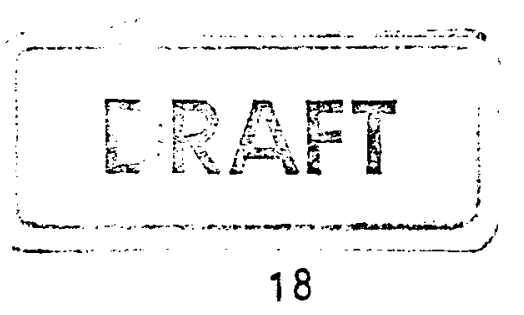




\section{$133 / 8$ inch casing}

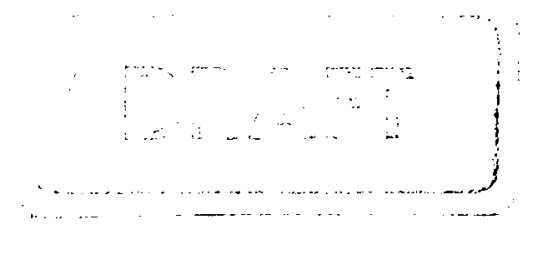

Specification: API grade C95, 68\#/ft, Buttress

Wall thickness $=0.48 "$

Joint Area (minimum) $=14.46 \mathrm{sq}$. in.

Cold yield $=95,000$ psi

Hot yield $=76,000$ psi

The results of the casing design for the above described 9 $5 / 8$ inch string to 6000 feet is shown in Table 3.1 . The $133 / 8$ inch design (not tabulated) produced similar results since, as explained above, the thermal stresses were similar for both strings and dominated the design. It is important to note that no corrosion allowance was included in the design calculations.

The complete casing design is given below: 30", conductor: 0-60', 118\#/ft plain end 20" conductor: $0-7001,94$ klft, k-55, LT\&C

$13 \mathrm{3} / 8^{n}$ intermediate: $0-30001,68 \# / f t, 695$, buttress

9 5/8" production: 0-6000', 47k/ft, C95, Buttress 7" slotter liner: 5800-10,000', 29" /ft, N80, LT\&C

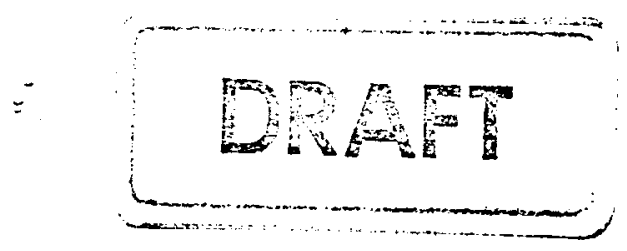




\subsection{Driling Program}

The production and injection wells that are needed for this project have been designed to meet the various requirements and problems that can develop in the drilling, testing and workover operations that will occur during their expected lifetimes. The well and casing diameters have been chosen to meet the expected drilling and completion activities. The minimum bit diameters used in successful geothermal operations is $81 / 2$ inches. This size has been chosen from experience associated with drilling high temperature, fractured reservoirs normalily encountered in geothermal environments.

Smaller bit sizes can be used in workover operations for cleanout. However, these sizes ( 6 inch diameter and smaller) do not last long in drilling operations. The bit life is important in drilling operations from the view that much of the time associated with drilling is used in running the drill pipe in and out of the wellbore. Moreover, these smaller bit diameters are run with smaller diameter drilling strings and bottomhole assemblies that withstand lower torque and tensional forces than those necessary to drill a usable hole in the deep geothermal environments. Deviation of the wellbore off vertical is also a problem with the small diameter drilling assemblies. Deviation should not be allowed to be greater than 1 degree per 100 feet or greater than 5 degrees at any depth. If deviation is greater 
than this the drilizng operation should be adjusted to straighten the hole back to vertical (slowly), maintaining the 1 degree per hundred foot criteria.

The deep hole production well is shown in Figure 4.1. The 60 feet of 30 inch casing is necessary to remove cuttings ano to assist in cementing of the 20 inch casing through shallow loss of circulation zones. The actual depth of this string will depend on how deep the auger bit drilling rig can bore a 36 inch hole. The advisory panel suggested that the normal practice in the area is to set the 20 inch casing to at least 700 feet. This casing string is needed for blow-out prevention when drilling the $171 / 2$ inch hole for the $133 / 8$ inch casing. The $133 / 8$ casing depth has been chosen for several reasons. The reservoir caprock is assumed to be at approximately 3000 feet from the temperature survey in well Elmore \#1 (see discussion in Section, 3). This 3000 foot depth is at the beginning of the point where the temperature versus depth begins to become isothermal. This casing depth will also seal off the shallow aquifers above the caprock that could be damaged if a blowout occurs when drilling the $121 / 4$ inch hole for the $95 / 8$ production string. Another reason for the 3000 foot setting depth is to minimize the amount of open hole in the wellbore at any one time.

It has also been alluded to that several gas pockets have 


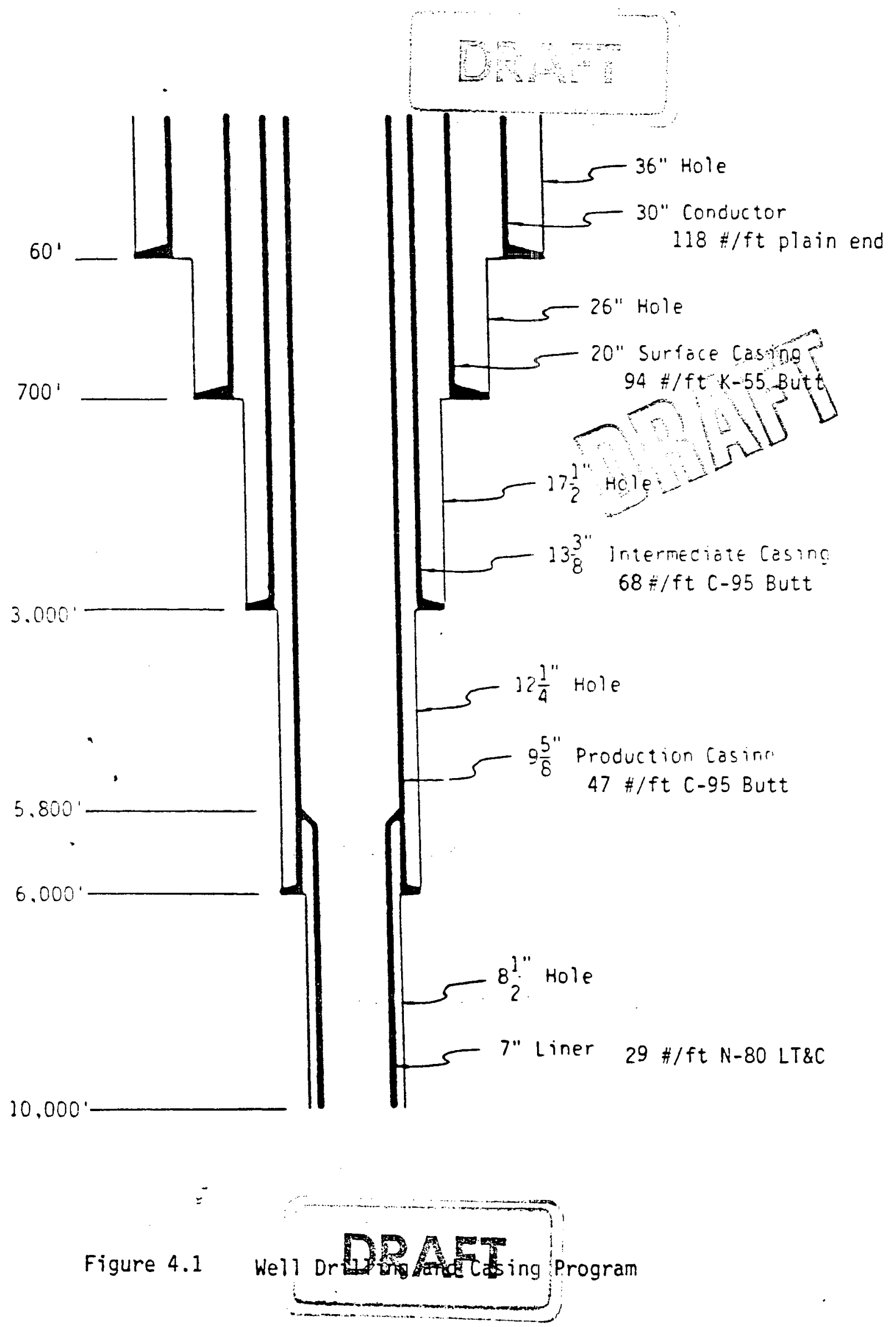


been found above 3000 feet. It will be advantageous to case through this zone before driling the higher temperature zones at greater depths.

The $95 / 8$ inch casing string spotid be set to at least 6000 feet. Maintaining the minimum amount of open hole is one reason. Other reasons have been discussed previously.

The lower uncased portion of the well is to be completed with an $81 / 2$ inch open hole. The minimum bit size discussed above has some impact on the choice of this diameter. Also, the well may be drilled deeper than the current target depth of 10,000 feet. This will require that 7 inch casing be set to as yet an undetermined depth. Welihead design conditions may change if a deeper completion results in higher temperature. Furthermore, if hole conditions get to the point where sloughing zones are causing drill pipe sticking or there are loss of circulation zones that can not be sealed off, then 7 inch casing will have to be set. Drilling would then have to proceed with 6 inch drill bits and the required bottom hole assemblies. This will hopefully not occur. However, we are drilling into unknown conditions at this site and should plan to meet these problems.

The corrosive characteristics of the brine in the salton sea area have been well documented. One solution to corrosion of the casing has been to run a production liner from surface to several hundred feet above the bottom casing point. The annulus

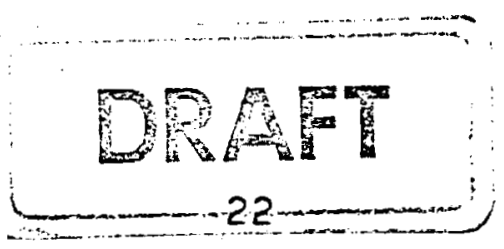


between the liner and the outside production string is filled with an inert compound (gas or liquid). The advisory panel has suggested that nitrogen be used as the annular fluid. This will require a 7 inch string hung in a packer assembly from the surface to about 5800 feet. Corrosion of this 7 inch liner will still occur; however, the $95 / 8$ production string will be protected by the nitrogen gas from the inside and by cement on the outside. If the 7 inch string corrodes, itcan be removed and replaced.

The design of the injection well incorporates a similar design methodology as discussed above. However, the completion is also based on the expected injection rates. The maximum injection rate is estimated to be $1000 \mathrm{gpm}$. A production liner has been recommended to lengthen the expected life of the well. The friction loss along the length of the wellbore needs to be included in the design of the well. The pressure loss for 7 inch casing and 5 inch casing is on the order of 2.5 psi/100 and 12 psi/100 for their respective casing diameters.

If 3500 feet of 5 inch casing were placed in the well, a pressure drop on the order of 420 psi would develop from friction losses associated with injection rates of $1000 \mathrm{gpm}$. This pressure drop plus the pressure increase from flow into the reservoir will have to be developed at the surface. For a 7 inch liner the friction losses for $1000 \mathrm{gpm}$ will be on the order

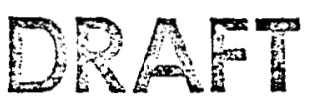




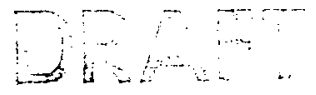

of $90 \mathrm{psi}$. From surface design considerations, this 90 psi pressure loss will be much easier to include into the surface injection facilities.

Workover operations to alleviate injection well damage are also included in the design considerations. The workover operations include: producing the injection weli, acidizing, scale removal, redrili ing and cleanout operatigns. If redrilling were necessary to obtain reservoir injectivity, the larger diameter casing in the well will allow for the most efficient strategy in recompletion.

The injection well also must be designed as a production well. The well should be produced immediately after completion. Testing of the well should be performed to determine reservoir and wellbore characteristics. An estimate of injectivity should be determined and monitored during injection testing and injection operations.

\subsection{Drilling Rates and Coring Operations}

The design of the drilling program includes several assumptions for driliing rates and estimates for the time necessary to case the well, run electrical logs, cement the casing to the borehole and flow test the well at the total depth. Approximátely $15 \%$ of the well will be cored at various

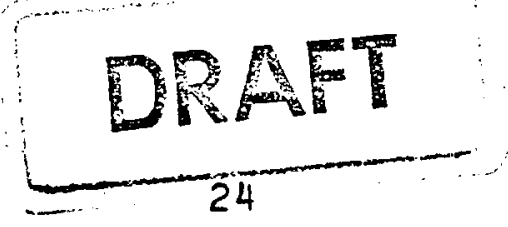


oepths.

The drilling rates, core rates, bit life, etc, used in the design are shown in Table 4.1 .

TABLE 4.1

Design Assumptions for Salton Sea Deep Well

\begin{tabular}{ccccccc} 
Depth & $\begin{array}{c}\text { bit } \\
\text { life } \\
\text { (hours) }\end{array}$ & $\begin{array}{c}\text { driling } \\
\text { rate } \\
(\mathrm{ft} / \mathrm{hr})\end{array}$ & $\begin{array}{c}\# \text { of } \\
\text { cores }\end{array}$ & $\begin{array}{c}\text { core } \\
\text { rate } \\
(\mathrm{ft} / \mathrm{hr})\end{array}$ & $\begin{array}{c}\text { \# of } \\
\text { bits }\end{array}$ & $\begin{array}{c}\# \text { of } \\
\text { core } \\
\text { bits }\end{array}$ \\
\hline $0-700$ & 45 & 15 & 0 & 0 & 1 & 0 \\
$700-3000$ & 80 & $12 \frac{1}{2}$ & 4 & 5 & 2 & 2 \\
$3000-6000$ & 48 & 10 & 18 & 5 & 5 & 3 \\
$6000-10000^{\circ}$ & 45 & 8 & 27 & 5 & 9 & 6
\end{tabular}

The rate at which the drill string is pulled out of the hole or run into the hole is 18 feet/minute ( 5 minutes per 90 feet). The time it takes to circulate the mud in the hole is assumed to be 40 minutes per 1000 feet when running into the hole or circulating before pulling out of the hole for coring operations. The coring operation itself requires several other 
operations as outlined below.

1) Circulate

2) Pull drill pipe out of hole

3) Stand back bottom hole assembly (collars, stabilizers, reamers, shock sub, bit)

4) Pick up core barrel and collars

5) Run drill pipe into hole

6) Circulate

7) Core interval

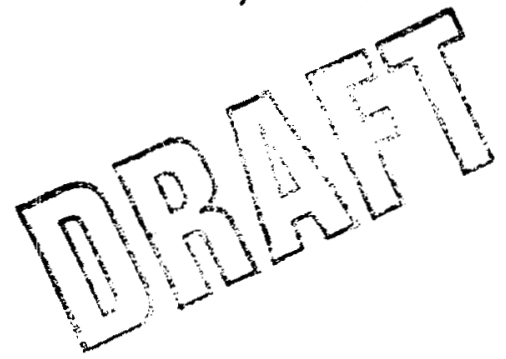

8) Pull drill pipe out of hole

9) Lay down core barrel, stand back collars

10) Pick up bottom hole assembly

11) Run drill pipe into hole

12) Circulate

13) Bègin driling

The total time to perform a given coring operation is 6 hours/1000 feet plus 8 hours (for pickup/laydown and 30 feet of core at a $5 \mathrm{ft} / \mathrm{hr}$ core rate). Thirty foot cores are assumed due to the difficulties associated with coring operations; mainly core barrel jamming, low volume circulation rates, fractured formations, high temperatures, etc.

Figure 4.2 illustrates the various times associated with the coring operation. As can be seen in the figure the time it takes to obtain 30 feet of core at 10,000 feet (assuming the 


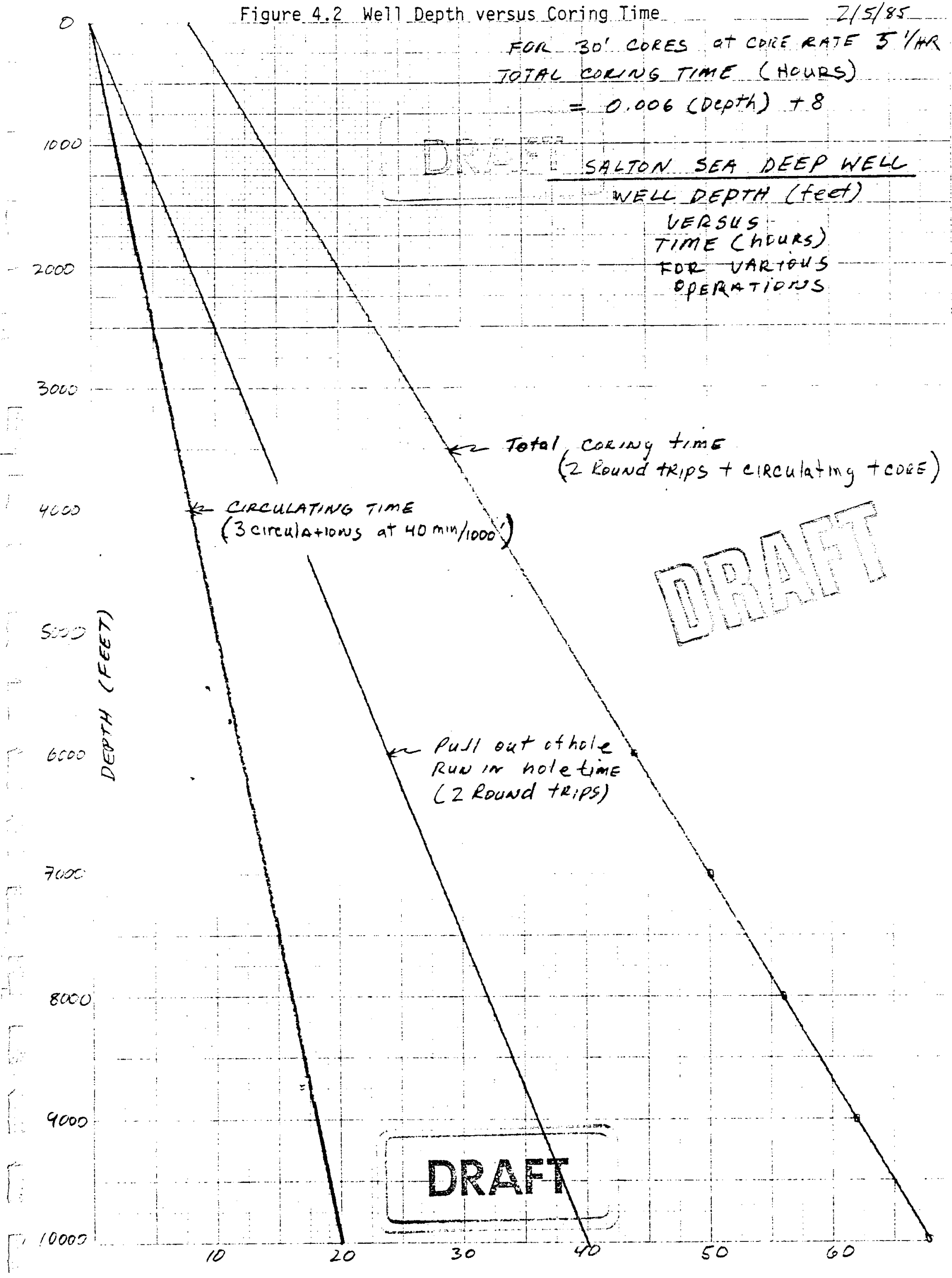


operation begins during driling and $t$ ads with driliing operations resuming) is 68 hours ( 2 days anc 20 hours). This is a time consuming operation at great depths. Choosing to obtain approximately 1500 feet of core yields the following drilling scenario:

1) 0-700 feet - no cores

2) $700-3000$ feet - drill 500 feet, core 30 feet - which
yields 4 cores $(120$ feet $)$

3) 3000-6000 feet-drill 120 feet, cort 30 feet which yields 18 cores ( 540 feet)

4) 6000-10,000 feet - drill 120 feet, cre 30 feet which yields 27 cores ( 810 feet)

The total program obtains core every 50 feet between 700 and 3000 feet and 30 feet of core every 10 feet of drilling from 3000 to 10,000 feet for a total of 49 cores. Additional coring times can be obtained from figure 4. for any specified depth.

The circulation rates discussed above (: J minutes/1000 feet) have been assumed for operations releva: t to drilling and coring. We have not modeled the exptated circulating temperature ( $T$ in, $T$ out) and circulating temperatures as a function of depth. The input required for these calculations has not been obtained by BGI to date. This input should include the times when the wellbore will be left (uiescent for some duration of time . The circulation rate. we have used are 


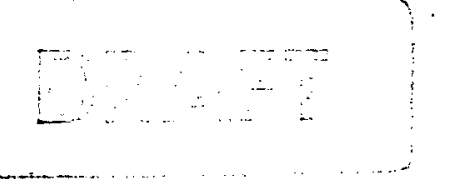

estimated for "breaking down" the mud in the well after it has set for a period of time and for the circulation time to remove cuttings from the wellbore before coring operations begin. Circulation times for cementing operations have also been assumed to allow for circulation of he annulus and for conditioning the mud.

Detailed circulation rates should be calculated before the well drilling is begun and should be updated during the drilling operation. Temperature changes along the length of the wellbore after it has been warmed should be minimized to reduce any large temperature changes that may damage the casing. We have not calculated what the allowable temperature change for a given time period should be at this time. Further investigation should be,performed in this area and the resulting guidelines maintained during the drilling operation. This will require that temperature versus depth surveys be taken periodically during the drilling activities.

The drilling rig size, capacity, and auxiliary equipment that will be needed to drill this well has been outlined in previous draft input to the drilling program plan. It will suffice here to state that the rig should be capable of drilling with $41 / 2$ inch drill pipe and have the ability to set a $95 / 8$ inch casing string to 10,000 feet. The rig should be capable of drilling to 16,000 feet. The circulating system should have

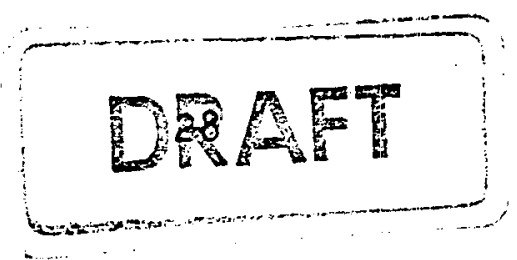


approximately 1000 barrels of surface volume and a dual pumping system ( 2 mud pumps) capabie of 1750-2000 Horsepower. Maximum circulation rates of up to 1000 gallons per minute should be obtainable when operating the mud pumps in parallel to the drill pipe. A $271 / 2$ inch rotary table with a 20 foot high substructure (for blow out prevention equipment) should be included.

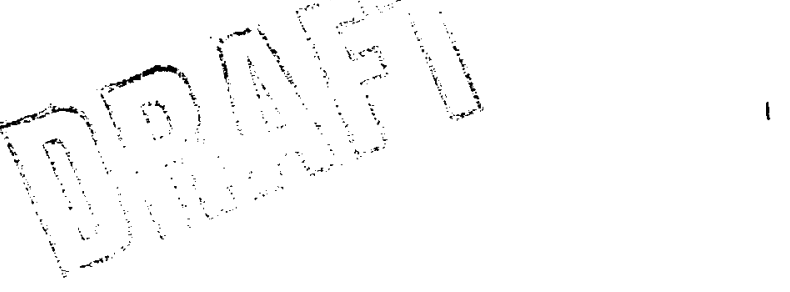




\subsection{Drilling Procedure with Daily Drilling Activities}

Table 5.1 is a condensed summary of the drilling activities associated with the Salton Sea Deep Well - SSDW drilling and coring project. The total drilling time includes the time associated with drilling, casing, cementing, logging and coring. A 36 hour flow test has been included at 10,000 feet (Total Depth). The various scientific activities that wijake place during the drilling and testing operations have not been included in our time estimates.

The total drilling time is estimated to be 152 days from the beginning of drilling the 26 inch hole to completing the well at 10,000 feet (open hole from 6000 to 10,000 feet). The assumptions for driliing rates, circulating times, etc, have been disqussed in section 4.0. The total drilling time includes only time spent drilling (i.e. rotating time). The coring time given in the summary is indicative of rotating hours to obtain core. Total time Running and Pulling out of hole and the total time circulating are the total time used in the various operations. The time used in the complete coring operation is on the order of 90 days. The total casing, cement, woc, logging, testing, etc time does not include the time needed to set a 7 inch production liner from 5800 to 10,000 feet or for a 7 inch hang-down liner from surface to 5600 feet.

The total number of drilling bits and core bits that are

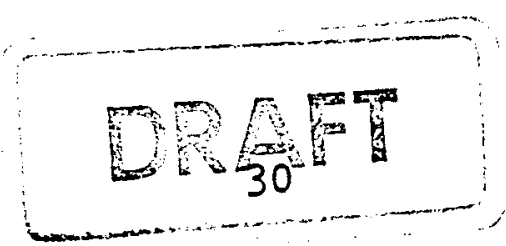


Table 5.1

Drilling Program Summary

Total Time

Total Drilling Time

\# of Bits

$$
\begin{aligned}
& 26^{\prime \prime} \\
& 17 \frac{1}{2} " 1 \\
& 12 \frac{1}{2} " 1 \\
& 8 \frac{2}{2} "
\end{aligned}
$$

Total Coring Time

\# of Core Bits

$$
\begin{aligned}
& 97 / 8^{11} \\
& 8 \frac{1}{2}=1
\end{aligned}
$$

Total Time Running in and

Pulling out of hole

Total Time Circulating

Total Time casing, cement, etc
3657 hours

152 days

\section{0 hours}

17

3

5

9

294 hours

12 days

11

5

6

1412 hours

59 days

691 hours

29 days

391 hours

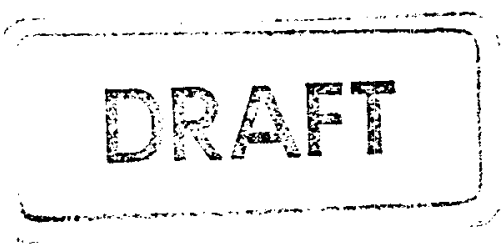


shown in Table 5.1 are estimated from the previous criteria. It is normal drilling practice to dispose of bits that show the slightest amount of wear. The bits will be pulled out of the hole to obtain cores after about one-third of their estimated useful life. This may require that the number of bits used to be increased by a factor of 2 to 3 times the values shown in the table. The same will aply to core bits anotherportions of the bottom hole assembly.

Figure 5.1 is a graph of well depth versus time for the driling operation to a total depth of 10,000 feet. The tables in Appendix A are a detailed listing of the estimated time for various drilling and coring operations on an hourly basis. These tables were used to develop Figure 5.1 It should be noted on the Figure that the depth versus time decreases at increasing depth. A comparison between Eigures 4.1 and 5.1 is instructive to this, point.

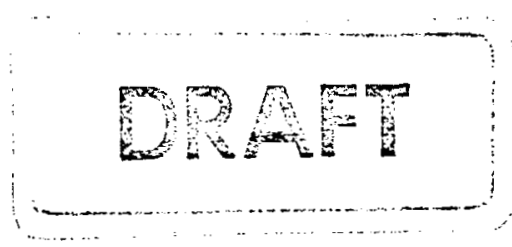




$$
\begin{aligned}
& \text { WELE DEPTH (feet) } \\
& \text { VERSUS TIME (days) }
\end{aligned}
$$

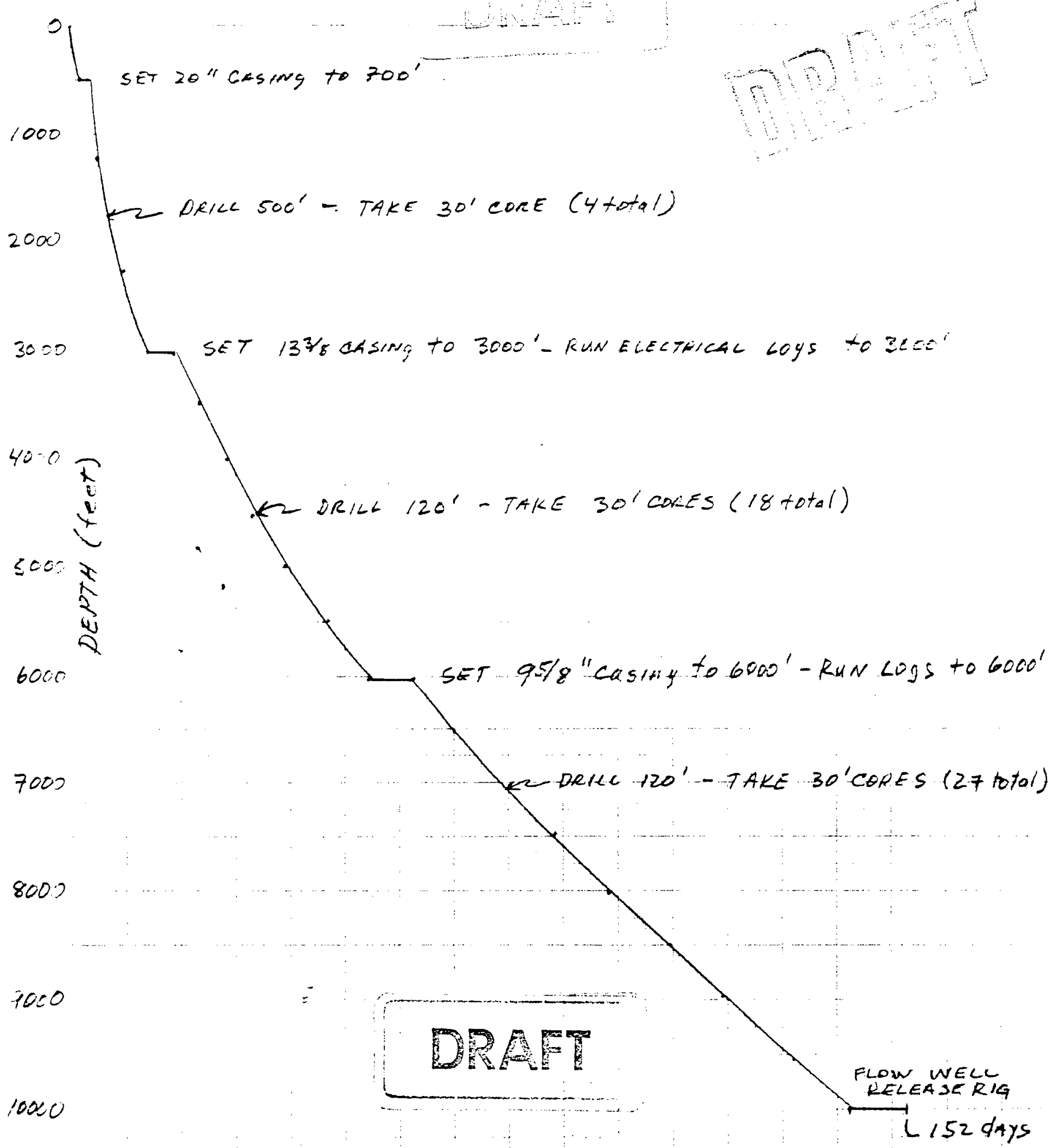

$0 \quad 102030 \quad 4050 \quad 6070 \quad 80 \quad 90100110120130140^{\prime}: 60160$ 


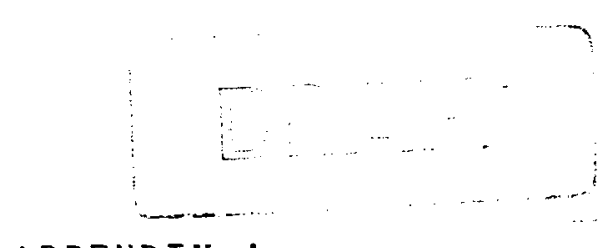

\section{APPENDIX A}

Daily Drilling Operations Versus Time and Depth

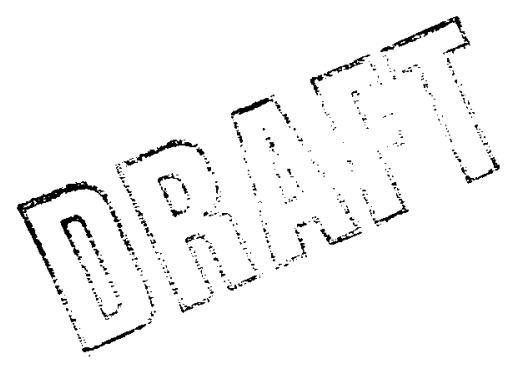

. 


\begin{tabular}{|c|c|c|c|c|c|c|c|c|c|c|c|c|c|c|c|}
\hline $\begin{array}{c}\text { DEPTH } \\
(f t)\end{array}$ & $\begin{array}{l}\text { TIME } \\
\text { (hrs) }\end{array}$ & OPERATION & $\left|\begin{array}{c}\text { TOTAL } \\
\text { TIME } \\
\text { hrs } / \text { day }\end{array}\right|$ & $\begin{array}{l}\text { TOTAL } \\
\text { DRILLIN } \\
\text { TIME } \\
\text { (hrs) }\end{array}$ & $\begin{array}{r}\text { TIME } \\
\text { ON BIT } \\
\text { (hrs) }\end{array}$ & $\begin{array}{c}\text { BIT } \\
\text { ysize }\end{array}$ & $\mid \begin{array}{r}\text { TIME ON } \\
\text { COREBIT } \\
\text { (hrs) }\end{array}$ & $\begin{array}{l}\text { TOTAL } \\
\text { CORING } \\
\text { TIME } \\
\text { (hrs) }\end{array}$ & $\left|\begin{array}{l}\text { COREBIt } \\
\text { H/size }\end{array}\right|$ & $\begin{array}{c}\text { POOH FIII } \\
\text { TOTAL. } \\
\text { TIMES } \\
\text { (hrs) }\end{array}$ & $\begin{array}{l}\text { TUIAL } \\
\text { CIRCULAT } \\
\text { TIlHE } \\
\text { (hrs) }\end{array}$ & $\begin{array}{l}\text { Casing } \\
\text { No Cement } \\
\text { Nop le }\end{array}$ & $\begin{array}{l}\text { \# of } \\
\text { Core }\end{array}$ & $\begin{array}{l}\text { CIRC } \\
\text { TIME }\end{array}$ & $\mid \begin{array}{l}\text { POOH } \\
\text { RIH } \\
\text { LAYOOWN }\end{array}$ \\
\hline \multirow[t]{4}{*}{700} & 48 & Drill 26" hole & $48 / 2$ & 45 & 48 & $1 / 26$ & & & & 1 & 2 & & & & \\
\hline & 4 & Run $20^{\prime \prime}$ casing & 52 & & & & & & & & & 4 & & & \\
\hline & 2 & Stabin & 54 & & & & & & & 2 & & & & & \\
\hline & 2 & Circulate & 56 & & & & & & & & 4 & & & & \\
\hline \multirow{3}{*}{ 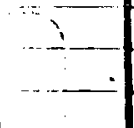 } & 2 & Cement & 58 & & & & & 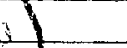 & & & & 6 & & & \\
\hline & 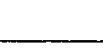 & Pull up chk float & & & & & & & & & & & & & \\
\hline & & Dump cement & & & & & & & & & & & & & \\
\hline \multirow{3}{*}{$\overline{-}$} & 1 & $\mathrm{POOH}$ - Lay down 26" & 59 & & & & & & & 3 & & & & & ' \\
\hline & 12 & wOC - Nipple up & 71 & & & & & 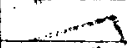 & & & & 18 & & & \\
\hline & & $20^{\prime \prime}$ flange & & & & & & & & & & & & & \\
\hline \multirow{3}{*}{$\ldots$} & & $20^{\prime \prime}$ spool & & & & & & & 1 & & & & & & \\
\hline & 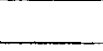 & $18^{\prime \prime} D G$ BOP & & & & & & & 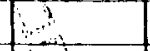 & & & & & & \\
\hline & & $20^{\prime \prime} \mathrm{ABOP}, \mathrm{RH}$ & & & & & & & +1 & & & & & & \\
\hline \multirow{4}{*}{ 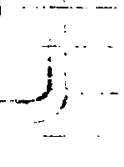 } & 6 & Pitcher Nipple & 77 & & & & & & 1 & & & 24 & & & \\
\hline & 3 & RIH w $17 !$ BHA & 80 & & & $2 / 17^{\prime}:$ & & $\because$ & & 6 & & & & & \\
\hline & 1 & Drillout 26" show & 81 & 46 & 1 & & & & & & & & & & \\
\hline & 40 & Drill to $1200^{\prime}$ & $121 / 5$ & 86 & 41 & & & & & & & & & & \\
\hline \multirow{2}{*}{$-\ldots$} & 1 & Circulate & 122 & & & & & & & & 5 & & & . & $\vdots$ \\
\hline & 1 & $\mathrm{POOH}$ & 123 & & & & & & & 7 & & & & & 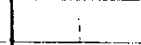 \\
\hline \multirow{3}{*}{$\ldots$} & 1 & PU core barrel & 124 & & ... & & & & $1 / 97 / 8$ & 8 & & & & & $\vdots$ \\
\hline & 1 & RIII & 125 & & & & & & & 9 & & & & & \\
\hline & 1 & Circulate & 126 & & & $\ldots$ & & & & & 6 & & & : & \\
\hline \multirow[t]{6}{*}{1230} & 6 & Core $30^{\circ}$ & 132 & & & & & 6 & & & 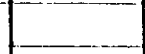 & & 1 & & \\
\hline & 1 & Circulate & 133 & & & & & & & & 7 & & & 1 & \\
\hline & 1 & $\mathrm{POOH}$ & 134 & & & & & & & 10 & & & & & \\
\hline & 1 & Lay down core B. & 135 & & & & & & & 11 & & & & & 1 \\
\hline & 1 & Pick up BHA & 136 & & & & & & & 12 & & & & & 1 \\
\hline & 1 & RIH & 137 & & & & & & & $\sqrt{3}$ & & & & & 1 \\
\hline & 1 & Circulate & 138 & & & & & & & & 125 & & & & \\
\hline
\end{tabular}




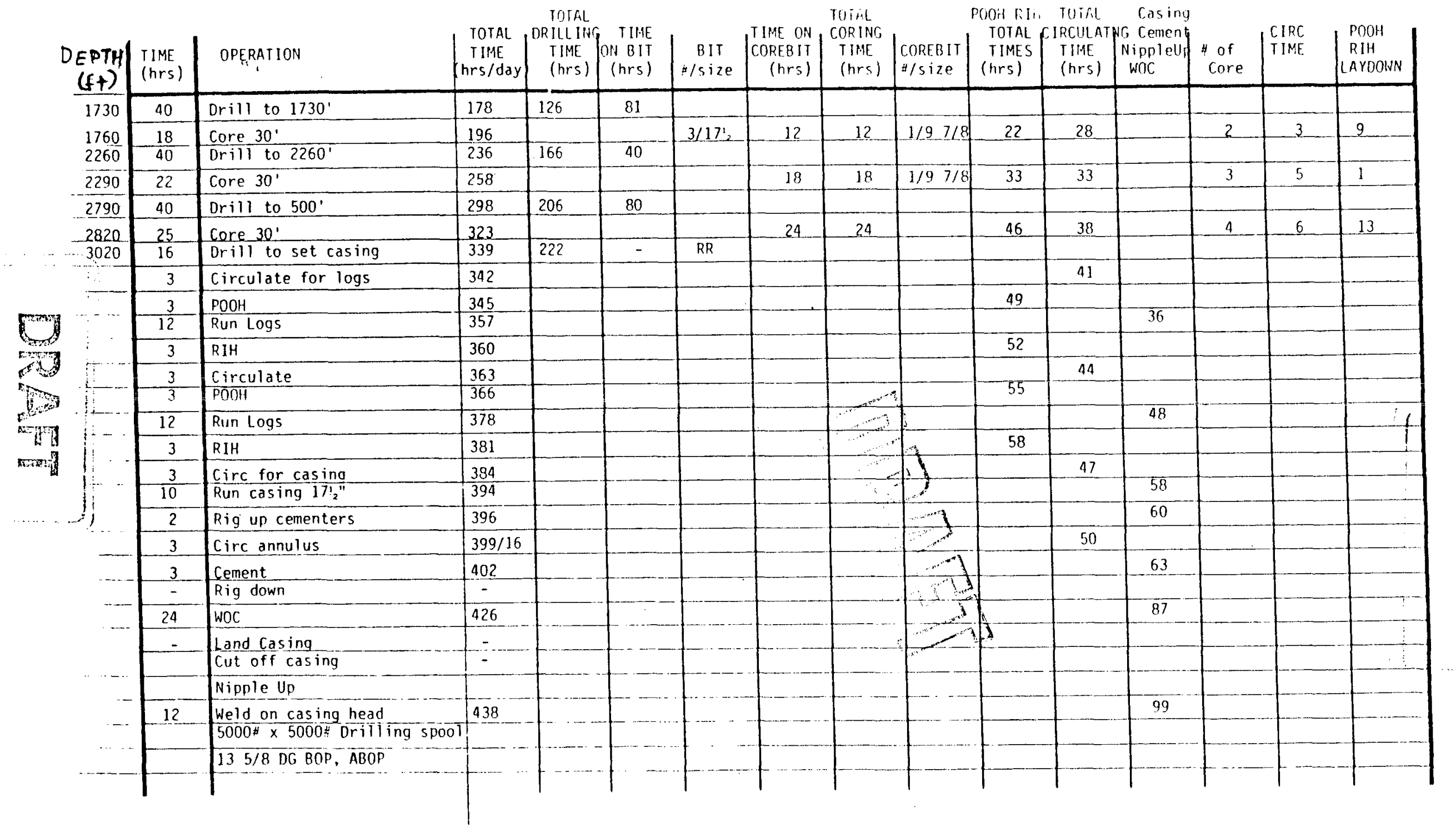




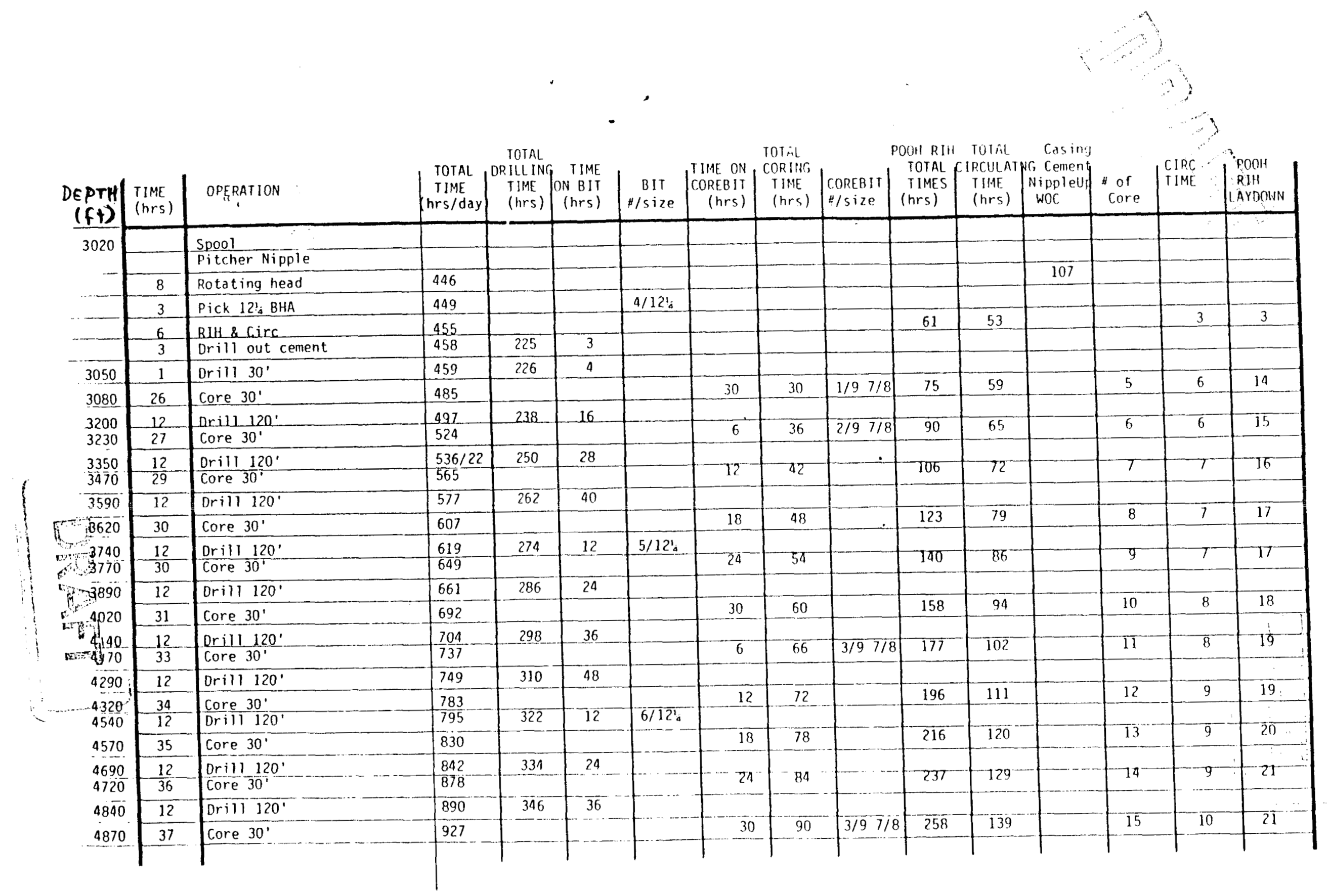




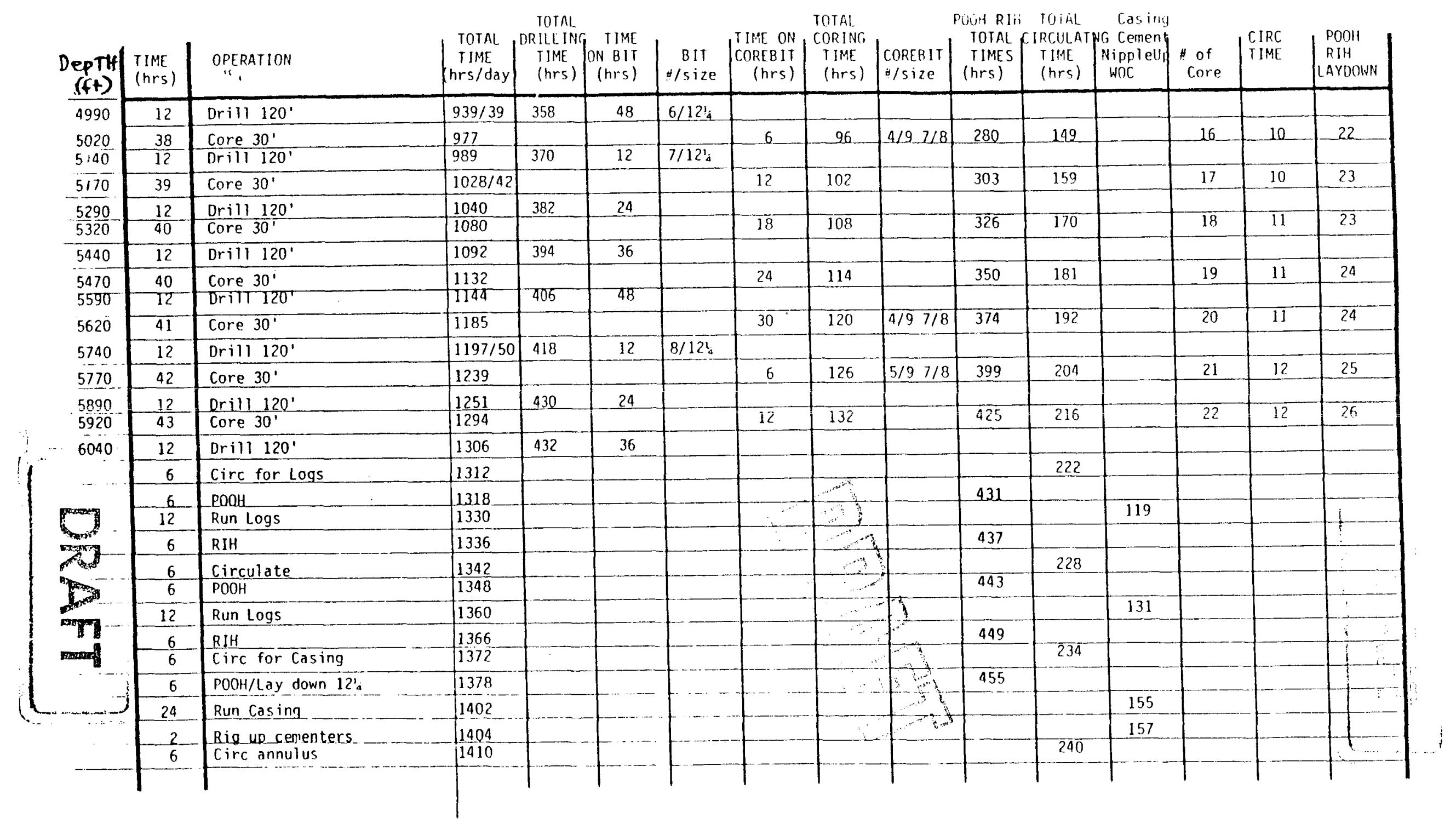




\begin{tabular}{|c|c|c|c|c|c|c|c|c|c|c|c|c|c|c|c|}
\hline $\begin{array}{c}\text { RETH } \\
(H)\end{array}$ & $\begin{array}{l}\text { TIME } \\
\text { (hrs) }\end{array}$ & $\begin{array}{l}\text { OPERATION } \\
",\end{array}$ & $\left|\begin{array}{c}\text { TOTAL } \\
\text { TIME } \\
\text { hrs/day }\end{array}\right|$ & $\begin{array}{l}\text { TOIRL } \\
\text { DRILLING } \\
\text { TIME } \\
\text { (hrs) }\end{array}$ & {$\left[\begin{array}{r}\text { TIHE } \\
\text { ON BIT } \\
\text { (hrs) }\end{array}\right.$} & $\begin{array}{c}\text { BIT } \\
* / \text { size }\end{array}$ & $\left|\begin{array}{r}\text { TIME ON } \\
\text { COREB IT } \\
(\text { hrs })\end{array}\right|$ & $\begin{array}{l}\text { TOTAL } \\
\text { CORING } \\
\text { TIME } \\
\text { (hrs) }\end{array}$ & $\mid \begin{array}{l}\text { COREBIT } \\
y / \text { size }\end{array}$ & $\begin{array}{l}\text { POOH RIH } \\
\text { TOIAL } \\
\text { TIMES } \\
\text { (hrs) }\end{array}$ & $\begin{array}{l}\text { TOTAL } \\
\text { CIRCULAT } \\
\text { TIME } \\
\text { (hrs) }\end{array}$ & $\begin{array}{l}\text { Casing } \\
\text { W Cement } \\
\text { Nipnleun } \\
\text { woC }\end{array}$ & $\begin{array}{l}\text { of } \\
\text { Core }\end{array}$ & CIRC & $\mid \begin{array}{l}\text { POOH } \\
\text { RIH } \\
\text { LAYDOWN }\end{array}$ \\
\hline 6040 & 10 & Cement & 1420 & & & & & & & & & 167 & & & \\
\hline & 2 & Rig down & 1422 & & & & & & & & -1 & 169 & & & \\
\hline & 24 & WOC & 1446 & & & & & & & $\cdots$ & 71 & 193 & & & \\
\hline & & Land Casing & & & & & & & & 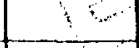 & 1 & & & & \\
\hline & $\ldots$ & Cut off casing & & & & & & . & & 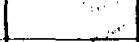 & $\cdots$ & & & & \\
\hline & & Nipple up & & & & & & & & $t$ & $\ldots$ & & & & \\
\hline & & Expansion spool & & & & & & & & 3 & $\therefore$ & 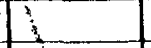 & & & \\
\hline & 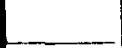 & $1500=$ Valve & & & & & & & & & $\therefore$ & 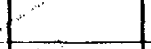 & & & \\
\hline & & Spool & & & & & & & & & 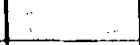 & 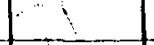 & & & \\
\hline & & $135 / 8 \mathrm{DG} B O P$ & & & & & & & & & & 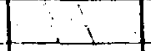 & & & \\
\hline & $:$ & Spool & & & & & & & & & & $\therefore \quad 2$ & & & \\
\hline 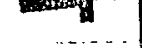 & & Pitcher Nipple & & & & & & & & & 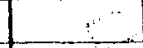 & $\cdots$ & & & \\
\hline & 24 & Rotating Head & 1470 & & & & & & & & & 217 & & & \\
\hline$\cdots-$ & 8 & Pickup 8: BHA w/6" collars & 1478 & & & $9 / \overline{8}_{2}$ & & & & 463 & & & & & \\
\hline & 6 & RIH & 1484 & & & & & & & 469 & & & & & \\
\hline & 6 & Circulate & $1490 / 62$ & & & & & & & & 246 & & & & \\
\hline 6080 & 8 & Drill out cement & 1498 & 440 & 8 & & & & & & & & & & \\
\hline 6170 & 45 & Core $30^{\prime}$ & 1543 & & & & 6 & 138 & $6 / 8_{2}^{1}$ & 495 & 258 & & 23 & 12 & 26 \\
\hline $\begin{array}{l}6230 \\
6260\end{array}$ & $\frac{15}{46}$ & $\frac{\text { Drill } 120^{\circ}}{\text { Core } 30^{\circ}}$ & $\frac{1558}{1604}$ & 455 & 23 & & $1 \overline{2}$ & 144 & & 522 & 271 & & 24 & 13 & 27 \\
\hline 6380 & 15 & Dril1 $120^{\circ}$ & $1619 / 67$ & 470 & 38 & & & & & & & & & & \\
\hline 6410 & 46 & Core $30^{\prime}$ & 1665 & & & & 18 & 150 & & 550 & 284 & & 25 & 13 & 28 \\
\hline $\begin{array}{l}6530 \\
6560\end{array}$ & 25 & Drill 120' & 1680 & 485 & 15 & $10 / 8_{2}^{\prime}$ & & & & 578 & 297 & & & 13 & \\
\hline 6560 & 47 & Core $30^{\circ}$ & 1727 & & & & 24 & 156 & & & 297 & & 26 & & 28 \\
\hline 6680 & 15 & Dril1 120 & 1742 & 500 & 30 & & & & & & & & & & \\
\hline 6710. & 48 & Core $30^{\circ}$ & 1800 & & & & 30 & 162 & $6 / 8^{\prime}=$ & 607 & 310 & & 27 & 13 & 29 \\
\hline 6830 & 15 & arill 120' & 1815 & 515 & 45 & & & & & & 324 & & 28 & 74 & 29 \\
\hline 6860 & 49 & Core $30^{\prime}$ & 1864 & & & & 6 & 168 & $7 / 8$ & 636 & 324 & & 28 & 14 & 29 \\
\hline
\end{tabular}




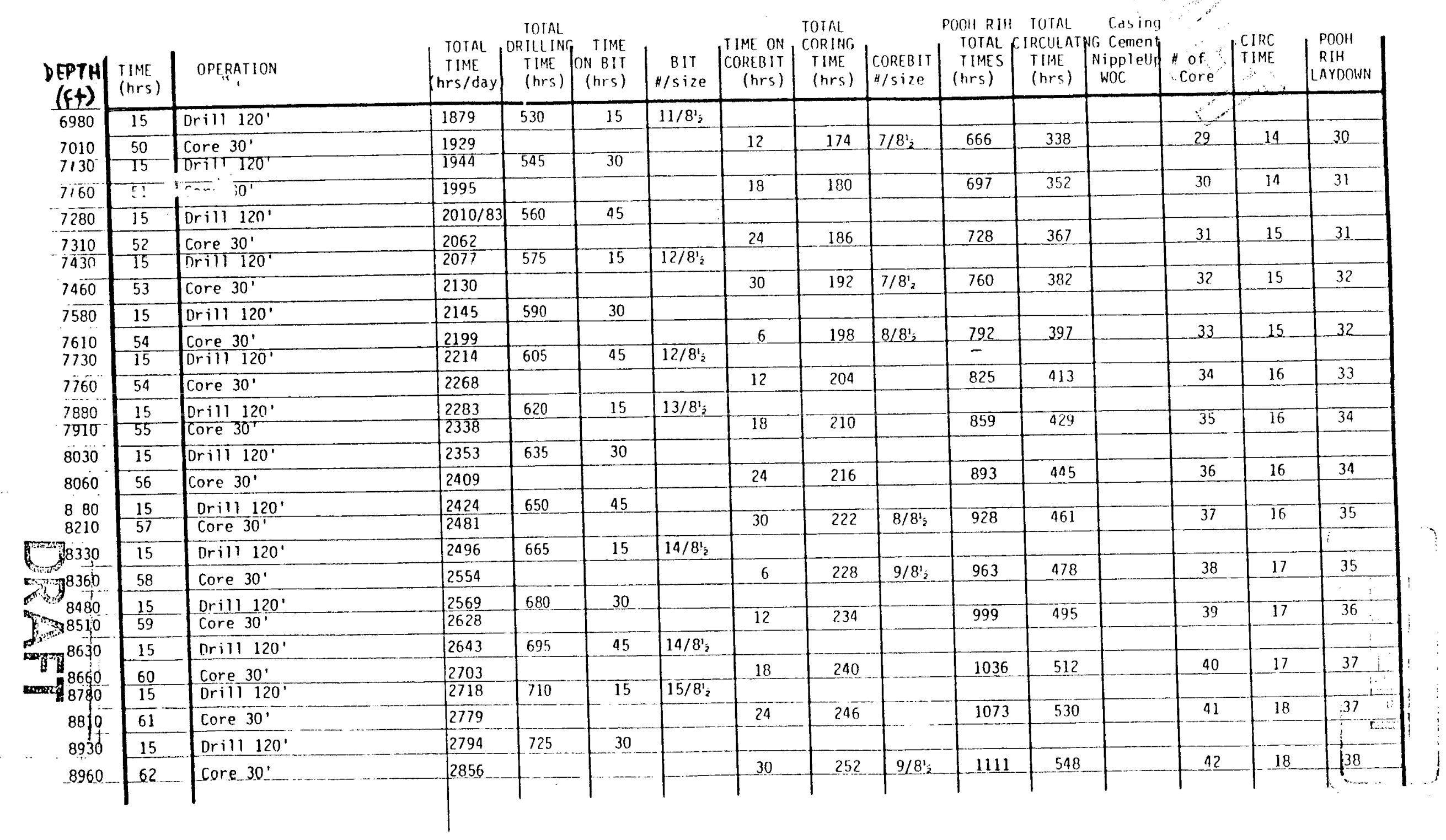




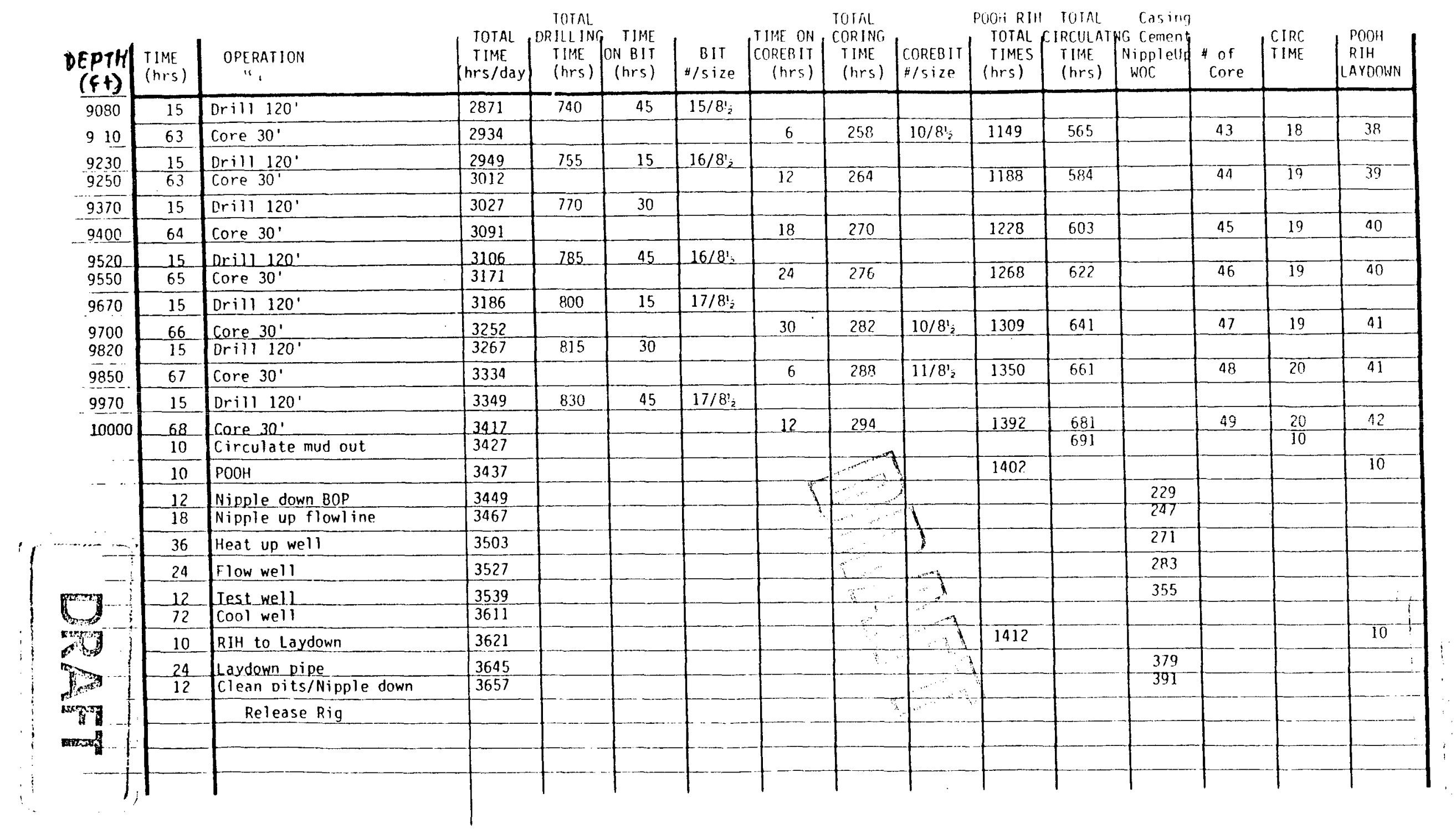

